\title{
EFEKTIFITAS PENDEKATAN CTL DAN PBL DENGAN SETTING KOOPERATIF TIPE STAD DITINJAU DARI KEMAMPUAN LITERASI MATEMATIS SISWA
}

\section{THE EFFECTIVITY OF CTL AND PBL APPROACH WITH STAD TYPE COOPERATIVE SETTING IN TERM OF STUDENTS' MATHEMATICAL LITERACY ABILITY}

\author{
Muhammad Arif Wicaksono ${ }^{1}$, Nina Agustyaningrum $*^{2}$ \\ ${ }^{1,2}$ Program Studi Pendidikan Matematika, Fakultas Keguruan dan Ilmu Pendidikan, Universitas Riau Kepulauan, \\ Batam, Kepulauan Riau, Indonesia \\ e-mail: ${ }^{1}$ muharifw123@gmail.com; ${ }^{2}$ nina@fkip.unrika@ac.id
}

\begin{abstract}
Abstrak
Tujuan penelitian ini adalah untuk mengetahui efektivitas pendekatan CTL dan PBL dengan setting kooperatif tipe STAD (Student Teams Achievement Divisions) ditinjau dari kemampuan literasi matematis siswa SMP Negeri 4 Batam. Penelitian ini merupakan jenis penelitian quasi experiment dengan Nonequivalent Control-Group Design. Populasi pada penelitian ini adalah seluruh siswa SMP Negeri 4 Batam kelas VIII, dengan sampel siswa kelas VIII $D$ dan kelas VIII E. Instrumen yang digunakan adalah tes kemampuan literasi matematis. Teknik analisis data menggunakan uji-t satu sampel untuk hipotesis 1 dan 2 serta uji-t polled varians untuk hipotesis 3 dengan taraf keyakinan 5\%. Hasil penelitian menunjukkan bahwa: (1) Pendekatan CTL dengan setting Kooperatif tipe STAD efektif ditinjau dari kemampuan literasi matematis siswa SMPN 4 Batam, (2) Pendekatan PBL dengan setting Kooperatif tipe STAD efektif ditinjau dari kemampuan literasi matematis siswa SMPN 4 Batam, dan (3) Tidak terdapat perbedaan efektivitas antara pendekatan CTL dan PBL dengan setting Kooperatif tipe STAD ditinjau dari kemampuan literasi matematis siswa SMPN 4 Batam.
\end{abstract}

Kata Kunci: Pendekatan CTL, Pendekatan PBL, Student Teams Achievement Divisions (STAD), Kemampuan literasi matematis

\begin{abstract}
This study aimed to know the effectiveness of CTL and PBL approach with STAD (Student Teams Achievement Divisions) type cooperative setting in term of students' matematical literacy abillity in SMP Negeri 4 Batam. This study can be categorized as quasi experiment research with using Nonequivalent Control-Group Design. The populations of this study was all $8^{\text {th }}$ grade students in SMP Negeri 4 Batam with the sample was students class VIII $D$ and class VIII E. The data were collected by using matematical literacy ability test. The analysis of data used one sample t-test for hypothesis land 2, and polled varians t-test for hypothesis 3 with a significance level 5\%. The result of this study showed that: (1) CTL approach with STAD type cooperative setting was effective in term of mathematical literacy ability, (2) PBL approach with STAD type cooperative setting was effective in term of mathematical literacy ability, (3) there wasn't any differences of effectiveness between CTL and PBL approach with setting of STAD cooperative type in term of matematical literacy abillity of $7^{\text {th }}$ grade students in SMP Negeri 4 Batam.
\end{abstract}

Keywords: CTL approach, PBL approach, Student Teams Achievement Divisions (STAD), matematical literacy abillity 


\section{PENDAHULUAN}

Pembaharuan dalam dunia pendidikan mengarah pada usaha memperkokoh potensi pendidikan nasional dalam mempersiapkan generasi muda untuk menghadapi perubahan ilmu pengetahuan dan teknologi. Untuk mewujudkan tujuan tersebut, pemerintah melakukan evaluasi ke luar dengan mengikuti berbagai jenis program penilaian proses pendidikan. Hal ini dilakukan sebagai sarana agar dapat menentukan posisi hasil pendidikan Indonesia dengan pendidikan bangsa lain. Berbagai jenis tes diselenggarakan secara internasional yaitu salah satunya keikutsertaan siswa Indonesia dalam programme for International Student Assessment (PISA) dan Trends in International Mathematic and Science Study (TIMSS) merupakan bukti nyata dalam upaya melihat sejauh mana program pendidikan di Indonesia.

Salah satu yang keterampilan yang disurvey oleh PISA adalah kemampuan literasi matematis. Menurut draft assassement PISA 2012 (dalam OECD, 2013), PISA mendefinisikan kemampuan literasi matematis sebagai berikut.

"Mathematical literacy is an individual's capacity to formulate, employ, and interpret mathematics in a variety of contexts. It includes reasoning mathematically and using mathematical concepts, procedures, facts, and tools to describe, explain, and predict phenomena. It assists individuals to recognise the role that mathematics plays in the world and to make the well-founded judgments and decisions needed by constructive, engaged and reflective citizens".

Berdasarkan definisi tersebut, literasi matematis diartikan sebagai kemampuan seseorang untuk merumuskan, menerapkan dan menafsirkan matematika dalam berbagai konteks, termasuk kemampuan melakukan penalaran secara matematis dan menggunakan konsep, prosedur, dan fakta untuk menggambarkan, menjelaskan atau memperkirakan fenomena/kejadian. Literasi matematis membantu seseorang untuk memahami peran atau kegunaan matematika di dalam kehidupan sehari-hari sekaligus menggunakannya untuk membuat keputusan-keputusan yang tepat sebagai warga negara yang membangun, peduli dan berpikir (Wardhani dan Rumiati, 2011: 11).

Indonesia telah mengikuti survey PISA pada tahun 2000, 2003, 2006, 2009 dengan hasil yang kurang memberikan perubahan dalam setiap keikutsertaannya. Pada tahun 2003 Indonesia berada di peringkat 38 dari 40 negara dalam bidang matematika. Pada tahun 2006 sedikit naik 
menjadi peringkat 50 dari 57 negara. Dan pada tahun 2009 hanya menempati peringkat 61 dari 65 negara (Balitbang, 2011).

Menurut Maryanti (2012: 6) indikator yang dapat menunjukkan bahwa seorang siswa bisa dikatakan literet apabila memiliki kemampuan sebagai berikut:

1) Merumuskan masalah atau memahami konsep matematika.

2) Menggunakan penalaran dalam memecahkan masalah.

3) Memecahkan masalah.

4) Menghubungkan kemampuan matematis dengan berbagai konteks.

5) Mengkomunikasikannya ke dalam bahasa matematis.

6) Menginterpretasikan kemampuan matematis dalam kehidupan sehari-hari dan berbagai konteks.

Dari hasil observasi yang dilakukan peneliti di SMP N 4 Batam, terdapat beberapa masalah yang dialami siswa yaitu kurangnya ketertarikan siswa untuk mempelajari matematika, kemudian kurangnya kepercayaan diri siswa untuk mengajukan pertanyaan apabila ada yang belum dipahami serta kurangnya kepercayaan diri dalam menjawab pertanyaan yang diberikan oleh guru. Keaktifan siswa masih sangat kurang ketika pembelajaran berlangsung. Di samping itu dalam kegiatan belajar mengajar, guru hanya memberikan konsep pembelajaran tanpa adanya proses menemukan konsep bersama-sama dengan siswa. Sehingga siswa menjadi pasif dan jenuh dalam belajar. Proses pembelajaran matematika yang dilaksanakan masih berorientasi pada penguasaan keterampilan dasar, hanya sedikit yang menekankan penerapan matematika dalam konteks kehidupan sehari-hari. Sehingga mengakibatkan hasil dan prestasi belajar matematika siswa menjadi rendah.

Selanjutnya, untuk memperkuat data awal maka peneliti memberikan tes literasi matematis sebanyak 2 soal kepada siswa. Dapat diketahui bahwa siswa belum mampu memecahkan permasalahan pada soal yang berkaitan dengan konteks kehidupan nyata. Terlihat pula bahwa siswa menjawab dengan singkat dan tidak tepat. Siswa belum mampu mengkomunikasikan informasi yang terdapat pada soal ke dalam jawaban mereka. Dari 78 siswa yang diberikan tes, hanya 14 orang yang dapat menjawab dengan benar. Sehingga dapat disimpulkan bahwa kemampuan literasi siswa kelas VIII masih kurang. Dalam penelitian ini adapun indikator dari kemampuan literasi matematis yang akan menjadi focus penelitian dibatasi pada indikator ke-3 
dan ke-4 yaitu memecahkan masalah dan menghubungkan kemampuan matematis dengan berbagai konteks. Hal ini disebabkan begitu luasnya indikator kemampuan literasi matematis sehingga dengan keterbatasan waktu penelitian yang ada penelitian difokuskan pada dua indikator saja.

Untuk mengatasi masalah kemampuan literasi matematis pada siswa, diperlukan sebuah setting pembelajaran yang dapat meningkatkan keaktifan dan melatihkan kemampuan literasi matematisnya. Penerapan pendekatan CTL (Contextual Teaching and Learning) dan PBL (Problem Based Learning) dengan setting kooperatif tipe STAD (Students Team Achievement Divisions) diharapkan dapat memotivasi siswa untuk belajar aktif dan dapat meningkatkan kemampuan literasi matematis siswa. Pendekatan CTL menurut Nurhadi (dalam Rusman, 2010: 189) adalah konsep belajar yang membantu guru mengaitkan antara materi yang diajarkan dengan situasi dunia nyata dan mendorong siswa membuat hubungan antara pengetahuan yang dimilikinya dengan penerapannya dalam kehidupan sehari-hari. Pendekatan PBL menurut Arends (dalam Putra, 2011: 19) adalah pembelajaran dengan pendekatan siswa pada masalah autentik sehingga siswa bisa menyusun pengetahuannya sendiri, menumbuh kembangkan keterampilan yang lebih tinggi dan inkuiri, memandirikan siswa, serta meningkatkan kepercayaan diri. Sedangkan pembelajaran Kooperatif tipe STAD merupakan salah satu tipe dari model pembelajaran kooperatif dengan menggunakan kelompok-kelompok kecil yang beranggotakan 4-5 orang siswa secara heterogen. Diawali dengan penyampaian tujuan pembelajaran, penyampaian materi, kegiatan kelompok, kuis, dan diakhiri dengan penghargaan kelompok.

Dalam pelaksanaannya, pembelajaran Kooperatif tipe STAD diharapkan mampu meningkatkan keaktifan dan minat belajar siswa karena pada model ini kelompok siswa yang mendapat nilai tertinggi mendapat reward dari guru serta meningkatkan keseriusan belajar siswa karena pada model pembelajaran ini hasil penilaian kelompoknya tergantung dari nilai perkembangan setiap individu. Kemudian digabungkan dengan pendekatan CTL dan PBL yang mengkaitkan pembelajaran dengan permasalahan kehidupan nyata sehingga diharapkan dapat meningkatkan kemampuan literasi matematis siswa. Sehingga tujuan dari penelitian ini adalah untuk mengetahui efektivitas pendekatan CTL dan PBL dengan setting kooperatif tipe STAD ditinjau dari kemampuan literasi matematis siswa SMP Negeri 4 Batam. 


\section{METODOLOGI PENELITIAN}

Penelitian ini merupakan jenis penelitian kuasi eksperimen dengan desain penelitian nonequivalent control-group design. Penelitian menggunakan dua kelompok sampel yang masing-masing diberikan trearment berupa pendekatan CTL dengan setting STAD dan pendekatan PBL dengan setting STAD. Untuk mengetahui kemampuan literasi matematis siswa, pada kelas ekperimen diberikan tes berupa pretes dan postes. Pretes untuk mengetahui kesetaraan kemampuan awal siswa pada kedua kelas tersebut. Sedangkan postes dilaksanakan untuk mengetahui pengaruh yang diberikan oleh suatu pembelajaran terhadap kemampuan yang diukur.

Gambaran dari Nonequivalent Control-Group Design untuk penelitian ini adalah sebagai berikut:

\section{Tabel 1. Gambaran Nonequivalent Control-Group Desain}

\begin{tabular}{cclc}
\hline Kelas & Tes awal (pretes) & Model & Tes akhir (postes) \\
\hline Eksperimen 1 & $\mathrm{T}_{1} \mathrm{E}_{1}$ & $\mathrm{X}_{1}$ & $\mathrm{~T}_{2} \mathrm{E}_{1}$ \\
Eksperimen 2 & $\mathrm{T}_{1} \mathrm{E}_{2}$ & $\mathrm{X}_{2}$ & $\mathrm{~T}_{2} \mathrm{E}_{2}$ \\
\hline Sumber: Sugiyono (2009: 116$)$ & &
\end{tabular}

Keterangan:

$\mathrm{T}_{1} \mathrm{E}_{1} \quad$ : Tes awal (Pretes) pada kelas eksperimen 1

$\mathrm{T}_{1} \mathrm{E}_{2}$ : Tes awal (Pretes) pada kelas eksperimen 2

$\mathrm{T}_{2} \mathrm{E}_{1} \quad$ : Tes akhir (Postes) pada kelas eksperimen 1

$\mathrm{T}_{2} \mathrm{E}_{2} \quad$ : Tes akhir (Postes) pada kelas eksperimen 2

$\mathrm{X}_{1} \quad$ : Pendekatan CTL setting STAD

$\mathrm{X}_{2} \quad$ : Pendekatan PBL setting STAD

Populasi dalam penelitian ini yaitu seluruh siswa kelas VIII SMP N 4 Batam Tahun Ajaran 2016/2017 yang terdiri dari kelas VIII A, VIII B, VIII C, VIII D, VIII E, VIII F, VIII G, VIII H, VIII I, VIII J dengan jumlah siswa sebanyak 388 orang siswa.. Pengambilan sampel pada penelitian ini yaitu dengan teknik Cluster Random Sampling. Menurut Sugiyono (2009: 83) cluster random sampling merupakan teknik sampling yang digunakan untuk menentukan sampel bila objek yang akan diteliti atau sumber data yang sangat luas. Dari hasil pengundian di antara kelas VIII A - VIII J peneliti mendapatkan dua kelas eksperimen yaitu kelas VIII D dan kelas VIII E. kelas VIII D dikenai pembelajaran CTL dengan setting STAD sementara kelas VIII E 
dikenali pembelajaran PBL dengan setting STAD. Penelitian ini dilaksanakan pada bulan Maret 2017 sampai dengan April 2017.

Variabel bebas dalam penelitian ini adalah pendekatan CTL dengan setting kooperatif tipe Student Team Acchievement Division (STAD) $\left(\mathrm{X}_{1}\right)$ dan Pendekatan PBL dengan setting kooperatif tipe Student Team Acchievement Division (STAD) $\left(\mathrm{X}_{2}\right)$. Variabel terikat dalam penelitian ini adalah kemampuan literasi matematis (Y) siswa dengan Literasi yang dinilai yaitu pada tingkatan level 3 dan level 4.

Teknik pengumpulan data yang digunakan dalam penelitian ini adalah menggunakan dokumentasi dan tes. Dokumentasi digunakan untuk mendapatkan data awal dari populasi penelitian, berupa daftar nama, jumlah siswa, dan daftar nilai ulangan akhir semester I siswa kelas VIII SMPN 4 Batam. Tes digunakan untuk mengetahui kemampuan literasi matematis siswa setelah melaksanakan pembelajaran berupa soal uraian sebanyak 2 soal untuk pre-test dan 2 soal untuk post-test.

Bukti untuk validitas instrumen dalam penelitian ini meliputi validitas isi (content validity). Validitas isi diperoleh dari penilaian ahli (expert judgment) menggunakan rumus aiken $\mathrm{V}$ (Kumaidi, 2014 dalam Retnawati, 2016: 18). Sedangkan untuk menguji reliabilitas instrumen tes dalam penelitan ini, digunakan rumus alfa Crombach karena jenis tes adalah essay. Hasil dari koefisien alfa Crombach pada instrumen pre-test dan post-test berturut-turut yaitu 0,664 dan 0,714 sehingga memiliki kriteria reliabilitas yang tinggi. Kemudian Daya Pembeda dan Tingkat kesukaran pada instrumen pre-test maupun post-test memiliki kriteria yang cukup.

Teknik analisis data untuk uji normalitas kemampuan awal atau pre-test dalam penelitian ini menggunakan uji chi kuadrat. Hasil analisis untuk uji normalitas pada data pre-test disajikan pad tabel 2 berikut.

Tabel 2. Hasil Uji Normalitas Data Pre-Test

\begin{tabular}{lcccccc}
\hline No & Kelas & $\mathrm{n}$ & $\chi_{\text {hitung }}^{2}$ & $\chi_{\text {tabel }}^{2}$ & Keputusan & Keterangan \\
\hline 1 & CTL + STAD & 37 & 6,81 & 11,070 & Ho diterima & Normal \\
2 & PBL + STAD & 37 & 2,54 & 11,070 & Ho diterima & Normal \\
\hline
\end{tabular}

Kemudian untuk menguji homogenitas pada data pre-test digunakan uji $\mathrm{F}$ dengan hasil seperti yang disajikan pada tabel 3 berikut. 
Tabel 3. Hasil Uji Homogenitas Varians Data Pre-Test

\begin{tabular}{ccccc}
\multirow{2}{*}{$\begin{array}{c}\text { Nilai Variansi } \\
\text { Sampel }\end{array}$} & \multicolumn{2}{c}{ Kelas } & & \\
\cline { 2 - 3 } & $\mathrm{F}_{\text {hitung }}$ & $\mathrm{F}_{\text {tabel(0,05;2,36) }}$ \\
\cline { 2 - 3 }$s^{2}$ & Experimen 1 & Experimen 2 & & \\
$n$ & 150,38 & 182,26 & 1,21 & 1,76 \\
\hline
\end{tabular}

Diperoleh F hitung adalah 1,21 sehingga menyimpulkan bahwa kedua kelompok memiliki varians yang homogen. Selanjutnya uji keseimbangan rata-rata kemampuan awal dari data pretest dilakukan menggunakan rumus uji t polled varians. Diperoleh bahwa t hitung adalah 0,582< $\mathrm{t}_{(0,05,72)} 1,99$ sehingga dapat disimpulkan bahwa tidak terdapat perbedaan rata-rata kemampuan awal pada kelas eksperimen 1 dan 2. Dari hasil ini, maka untuk menguji hipotesis penelitian 1 dan 2 akan dianalisis langsung dari hasil post test.

Uji hipotesis 1 dan 2 menggunakan uji t satu sampel, sedangkan untuk uji hipotesis 3 menggunakan uji t polled varians dengan taraf keyakinan 5\%.

\section{HASIL PENELITIAN DAN PEMBAHASAN}

\section{Hasil Penelitian}

Setelah dilakukan perlakuan pembelajaran pada kelas eksperimen 1 dengan pendekatan CTL dengan setting kooperatif tipe STAD dan pada kelas eksperimen 2 dengan pendekatan PBL dengan setting kooperatif tipe STAD diperoleh data hasil pre-test dan hasil post-test sebagai berikut:

Tabel 2. Deskripsi Data pre-test dan post-test

\begin{tabular}{lcccc}
\hline \multirow{2}{*}{ DESKRIPSI DATA } & \multicolumn{2}{c}{ PRE-TEST } & \multicolumn{2}{c}{ POST-TEST } \\
\cline { 2 - 5 } & $\mathrm{X}_{1}$ & $\mathrm{X}_{2}$ & $\mathrm{X}_{1}$ & $\mathrm{X}_{2}$ \\
\hline Rata-rata & 41.406 & 39,516 & 65,405 & 62,432 \\
$\mathrm{~S}$ & 12,263 & 13,5 & 8,77 & 11,032 \\
$\mathrm{~S}^{2}$ & 150,38 & 182,26 & 76,91 & 121,697 \\
Skor Tertinngi & 65 & 70 & 80 & 80 \\
Skor Terendah & 20 & 15 & 45 & 40 \\
skor Ideal Tertinggi & 100 & 100 & 100 & 100 \\
Skor Ideal Terendah & 0 & 0 & 0 & 0 \\
Jumlah siswa & 32 & 31 & 37 & 37 \\
\hline
\end{tabular}


Dari data tersebut diketahui bahwa terjadi peningkatan dari hasil pre-test dan hasil post-test pada kedua kelompok sampel. Diperoleh juga bahwa selisih pre-test dan post-test pada kelas eksperimen 1 lebih tinggi daripada kelas eksperimen 2 yaitu yaitu 23,996 dan 22,916.

\section{Uji Prasyarat Data}

Sebelum data dianalisis untuk menguji hipotesis, terlebih dahulu data harus memenuhi syarat normalitas dan homogenitas. Data diperoleh dari hasil post-test yang diberikan setelah perlakuan pada kelompok sampel selesai dilaksanakan. Pada uji prasyarat ini, uji normalitas menggunakan uji chi kuadrat, sedangkan uji homogenitas menggunakan uji F.

1. Uji Normalitas

Setelah dilaksanakan penelitian atau perlakuan terhadap kelas eksperimen 1, sampel diberikan soal post-test untuk mengetahui sejauh mana perkembangan kemampuan siswa. Setelah mendapat data hasil post-test tersebut maka dilakukan uji normalitas. Diperoleh hasil analisis data post-test untuk uji normalitas sebagai berikut:

Tabel 3. Hasil Uji Normalitas Data Post-Test

\begin{tabular}{lcccccc}
\hline No & Kelas & $\mathrm{n}$ & $\chi_{\text {hitung }}^{2}$ & $\chi_{\text {tabel }}^{2}$ & Keputusan & Keterangan \\
\hline 1 & CTL + STAD & 37 & 2,91 & 11,070 & Ho diterima & Normal \\
2 & PBL + STAD & 37 & 4,72 & 11,070 & Ho diterima & Normal \\
\hline
\end{tabular}

2. Uji Homogenitas

Uji homogenitas dilakukan dengan membandingkan nilai variansi data nilai post-test dari kelas eksperimen 1 dan kelas eksperimen 2. Kemudian dari nilai post-test diperoleh nilai variansi sampel sebagai berikut:

Tabel 4. Nilai Varians Kedua Kelompok Sampel

\begin{tabular}{ccccc}
\hline \multirow{2}{*}{$\begin{array}{c}\text { Nilai Variansi } \\
\text { Sampel }\end{array}$} & \multicolumn{2}{c}{ Kelas } & \multirow{2}{*}{$\mathrm{F}_{\text {hitung }}$} & $\mathrm{F}_{\text {tabel(0,05;2,36) }}$ \\
\cline { 2 - 3 } & Experimen 1 & Experimen 2 & & \\
\hline$s^{2}$ & 76,914 & 121,697 & \multirow{2}{*}{1,582} & 1,76 \\
$n$ & 37 & 37 & & \\
\hline
\end{tabular}

Dari hasil perhitungan diperoleh harga $F_{\text {hitung }}$ 1,582. Harga $F_{\text {hitung }}$ tersebut kemudian dibandingkan dengan $F_{\text {tabel }}=1,76$. Karena $F_{\text {hitung }}<F_{\text {tabel }}(1,582<1,76)$, maka dapat disimpulkan bahwa hasil post-test dari kedua kelas tersebut memiliki varians yang homogen. 


\section{Uji Hipotesis 1}

Kelas ekeperimen 1 pada penelitian ini adalah kelas VIII D SMPN 4 Batam dengan menggunakan pendekatan CTL dengan setting kooperatif tipe STAD. Sebelum dilakukan uji hipotesis 1 , terlebih dahulu mencari $\mu_{0}$ atau nilai rata-rata yang dihipotesiskan dengan langkah sebagai berikut (Sugiyono, 2009: 178).

a) Mencari skor ideal

(Skor tertinggi) x (jumlah item instrumen) x (jumlah responden)

b) Mencari skor yang diharapkan

(Jumlah skor tes) : (skor ideal)

c) Mencari rata-rata skor ideal

(Skor ideal) : (jumlah responden)

d) Mencari nilai yang dihipotesiskan

$\mu_{0}=($ skor yang diharapkan) $\mathrm{x}$ (rata-rata skor ideal)

Diperoleh bahwa $\mu_{0}=54,27$, sehingga dengan rumus uji one sample t test diperoleh harga $t_{\text {hitung }}$ $=7,723$ pada taraf signifikan 5\%. Kriteria keputusan adalah menerima Ho jika $t_{\text {hitung }}<t_{\text {tabel }}$ dan sebaliknya menolak Hojika $t_{\text {hitung }}>\mathrm{t}_{\text {tabel }}$. Hasil $\mathrm{t}_{\text {hitung }}$ yaitu 7,723 lebih besar dari $\mathrm{t}_{\text {tabel }}(0,05 ; 36)$ yaitu 1,687 sehingga Ho ditolak dan Ha diterima. Artinya pendekatan CTL dengan setting kooperatif tipe STAD efektif ditinjau dari kemampuan literasi matematis siswa SMPN 4 Batam.

\section{Uji Hipotesis 2}

Kelas ekeperimen 2 pada penelitian ini adalah kelas VIII E SMPN 4 Batam yang dikenai pendekatan PBL dengan setting kooperatif tipe STAD. Sebelum dilakukan uji hipotesis 2, terlebih dahulu mencari $\mu_{0}$ atau rata-rata yang dihipotesiskan dengan langkah sama seperti langkah untuk mencari $\mu_{0}$ pada uji hipotesis 1 . Dari hasil perhitungan didapat bahwa $\mu_{0}=52$. Selanjutnya dengan menggunakan rumus uji one sample $t$ test diperoleh $t_{\text {hitung }}=5,752$. Hasil $\mathrm{t}_{\text {hitung }}$ pada kelas eksperimen 2 yaitu 5,752 dibandingkan dengan $\mathrm{t}$ tabel pada $\mathrm{dk}=36$ dan alpha $5 \%$ menghasilkan $t_{\text {tabel }}=1,687$. Karena $t_{\text {hitung }}>t_{\text {tabel }}(5,752>1,687)$, maka Ho ditolak dan Ha diterima. Artinya pendekatan PBL dengan setting Kooperatif tipe STAD efektif ditinjau dari Kemampuan Literasi Matematis Siswa SMP N 4 Batam. 


\section{Uji Hipotesis 3}

Hipotesis ketiga pada penelitian ini bertujuan untuk mengetahui apakah terdapat perbedaan keefektifan antara pendekatan CTL dan PBL dengan setting kooperatif tipe STAD ditinjau dari kemampuan literasi matematis siswa SMPN 4 Batam. Pengujian hipotesis dilakukan dengan rumus poolled varians $t$ test. Kriteria keputusan Ho diterima jika $t_{\text {hitung }}<t_{\text {tabel }}$ sedangkan sebaliknya Ho ditolak jika $t_{\text {hitung }}>t_{\text {tabel }}$. Berdasarkan perhitungan diperoleh nilai $t_{\text {hitung }}=1,28$. Untuk harga $\mathrm{t}$ tabel dengan $\mathrm{dk}=\mathrm{n}_{1}+\mathrm{n}_{2}-2=72$ dan alpha $5 \%$ diperoleh $\mathrm{t}_{\text {tabel }}=1,99$. Karena $t_{\text {hitung }}<t_{\text {tabel }}(1,28<1,99)$, maka Ho diterima yang artinya tidak terdapat perbedaan efektivitas antara pendekatan CTL dan PBL dengan setting kooperatif tipe STAD ditinjau dari kemampuan literasi matematis siswa SMP Negeri 4 Batam.

\section{Pembahasan}

Pada hipotesis 1 dan 2 diperoleh kesimpulan bahwa pendekatan CTL dan PBL dengan setting kooperatif STAD maisng-masing efektif ditinjau dari kemampuan literasi matematis siswa. Dalam pelaksanaan proses pembelajaran menggunakan pendekatan CTL setting kooperatif tipe STAD siswa melakukan proses mengamati sebuah media pembelajaran kontekstual yang relevan dengan materi yang dipelajari sehingga menjadikan pemahaman yang lebih terkonsep. Siswa mendapat pengetahuan baru dengan bantuan media yang nyata. Kemudian terdapat kelebihan dari pelaksanaan pendekatan CTL yang mendukung bukti bahwa pembelajaran dapat efektif yaitu pembelajaran lebih produktif dan mampu menumbuhkan penguatan konsep karena terdapat tahap konstruktivisme, dimana siswa dituntun menemukan pengetahuannya sendiri (Hosnan, 2014: 279). Disamping itu, dalam pendekatan CTL pada dasarnya ialah menyampaikan pembelajaran dengan menghubungkan materi dengan konteks nyata sehingga sangat berkaitan dengan kemampuan literasi matematis yang merupakan kemampuan untuk merumuskan dan menafsirkan matematika dalam berbagai konteks. Hal ini sesuai dengan hasil penelitian Umbara (2015: 1) yang menyimpulkan bahwa pembelajaran kontekstual dapat meningkatkan kemampuan literasi matematika siswa. Selain itu, respon yang diberikan oleh siswa pun sangat baik sehingga pembelajaran kontekstual dapat dijadikan suatu alternative pembelajaran bagi guru matematika.

Selanjutnya, pada penerapan pembelajaran pendekatan PBL dengan setting kooperatif tipe STAD menekankan pada pembelajaran yang berbasis masalah sehari-hari. Sehingga pada 
pelaksanaannya siswa diberikan permasalahan sehari-hari dalam menemukan konsep untuk didiskusikan bersama kelompoknya. Langkah-langkah dalam PBL membantu siswa untuk memproses informasi yang sudah dimiliki dan menyusun pengetahuan mereka untuk memahami konsep baru yang dipelajari. Hal inilah yang membuat pendekatan PBL dengan setting kooperatif STAD efektif dalam menunjang kemampuan literasi matematis siswa. Hasil penelitian ini sejalan dengan hasil penelitian yang dilaporkan oleh Indah, dkk (2016: 202) yang menemukan bahwa penerapan model pembelajaran Problem Based Learning dapat meningkatkan kemampuan literasi matematika pada siswa kelas VII SMP Negeri 5 Pallangga Kabupaten Gowa.

Pada hasil pengujian hipotesis ketiga diperoleh kesimpulan bahwa tidak terdapat perbedaan keefektifan pendekatan CTL dan PBL dengan setting kooperatif tipe STAD ditinjau dari kemampuan literasi matematis siswa. Namun berdasarkan hasil pengujian hipotesis 1 dan 2 diketahui bahwa kedua pembelajaran ini sama-sama efektif dan memiliki nilai rata-rata post-test yang tidak jauh berbeda. Dalam pelaksanaan pembelajarannya juga sangat tidak jauh berbeda seperti pada pendekatan CTL setting STAD siswa diberikan media pembelajaran dimana para siswa mengamati dan berdiskusi untuk menemukan sebuah konsep sesuai dengan arahan LKS. Setiap penyampaian materi selalu dihubungkan dengan konteks kehidupan nyata. Sama halnya dengan pendekatan PBL setting STAD siswa diberikan permasalahan yang berkaitan dalam konteks nyata untuk menemukan konsep baru. Penyampaian materi juga harus mengkaitkan dengan kehidupan sehari-hari. Sehingga kedua model pembelajaran tersebut hampir sama karena sama-sama menghubungkan materi yang diajarkan dalam konteks kehidupan sehari-hari. Yang membedakan hanya cara menemukan sebuah konsep baru dalam diskusi kelompok siswa. Oleh sebab itu, kedua pembelajaran ini dapat direkomendasikan untuk mendukung melatihkan kemampuan literasi matematis siswa.

\section{KESIMPULAN DAN SARAN}

\section{Kesimpulan}

Berdasarkan hasil analisis, dapat diperoleh kesimpulan sebagai berikut.

1. Pendekatan CTL dengan setting Kooperatif tipe STAD efektif ditinjau dari kemampuan literasi matematis siswa. Hal ini dapat dilihat dari pengujian hipotesis dengan uji one sample 
t test yang memperkuat hasil penelitian ini dengan membandingkan $t_{\text {hitung }}$ dengan $\mathrm{t}_{\text {tabel }}$ dimana $t_{\text {hitung }}>\mathrm{t}_{\text {tabel }}(7,723>1,687)$ sehingga Ho ditolak dan Ha diterima.

2. Pendekatan PBL dengan setting Kooperatif tipe STAD efektif ditinjau dari kemampuan literasi matematis siswa. Dari hasil pengujian hipotesis dengan one sample t test diperoleh $t_{\text {hitung }}>t_{\text {tabel }}(5,752>1,687)$ sehingga Ho ditolak dan Ha diterima.

3. Tidak terdapat perbedaan efektivitas antara pendekatan CTL dan PBL dengan setting Kooperatif tipe STAD ditinjau dari kemampuan literasi matematis siswa. Hal ini dapat dilihat dari pengujian hipotesis dengan uji t poolled varians yang memperkuat hasil penelitian ini dengan membandingkan $t_{\text {hitung }}$ dengan $t_{\text {tabel }}$ dengan $t_{\text {hitung }}=1,28$ dan $t_{\text {tabel }}=1,99$. Karena $t_{\text {hitung }}$ $<t_{\text {tabel }}$ sehingga Ho diterima.

\section{Saran}

Dari pembahasan dan kesimpulan yang diperoleh, dapat diberikan beberapa saran sebagai berikut.

1. Pendekatan CTL dan PBL dengan setting kooperatif tipe STAD dapat dijadikan sebagai alternatif pembelajaran untuk menunjang kemampuan literasi matematis siswa.

2. Peneliti dapat mencoba pendekatan CTL dan PBL dengan setting model kooperatif yang lain sebagai variasi dalam menerapkan model pembelajaran matematika yang menyenangkan.

\section{REFERENSI}

Badan Penelitian dan Pengembangan (Balitbang). (2011). PISA (Programme for International Students Assesment). Kementrian Pendidikan dan Kebudayaan.

Hosnan, M. (2014). Pendekatan Saintifik dan Kontekstual dalam Pembelajaran Abad 21. Bogor: Ghalia Indonesia.

Indah, N., Mania, S., \& Nursalam .(2016). Peningkatan Kemampuan Literasi Matematika Siswa Melalui Penerapan Model Pembelajaran Problem Based Learning di Kelas VII SMP Negeri 5 Pallangga Kabupaten Gowa. Jurnal Matematika dan Pembelajaran (MaPan), Vol. 4, No. 2. Tersedia di: http://journal.uin-alauddin.ac.id/index.php/Mapan/article/view/3247. [31 Desember 2018]

Maryanti, E. (2012). Peningkatan Literasi Matematis Siswa Melalui Pendekatan Metacognitive Guidance. Tesis UPI Bandung.

OECD. (2013). Draft PISA 2012 Assesment Framework. [Online]. Tersedia di: http://www.oecd.org/pisa/pisaproducts/46961598.pdf. [26 Desember 2016]. 
Putra, E. (2011). Eksperimentasi Pembelajaran Matematika Dengan Problem Based Learning Dan Cooperative Learning Tipe STAD Ditinjau Dari Gaya Belajar Siswa. Tesis UNS Surakarta.

Retnawati, H. (2016). Analisis Kuantitatif Instrumen Penelitian (Panduan Peneliti, Mahasiswa, dan Psikometrian). Yogyakarta: Parama Publishing.

Rusman. (2010). Model-Model Pembelajaran: Mengembangkan Profesionalisme Guru. Jakarta: Rajawali Pers.

Sugiyono. (2009). Metode Penelitian Kuantitatif, Kualitatif dan R\&D. Bandung: Alfabeta.

Umbara, U. (2015). Implementasi Pembelajaran Kontekstual Terhadap Kemampuan Literasi Matematis Siswa SMP. JUMLAHKU: Jurnal Matematika Ilmiah STKIP Muhammadiyah Kuningan, $\quad$ Vol $1, \quad$ No. $1, \quad$ Tersedia di: http://jurnal.upmk.ac.id/index.php/jumlahku/article/view/116 [31Desember 2018]

Wardhani, S., dan Rumiati. (2011). Instrumen Penilaian Hasil Belajar Matematika SMP: Belajar dari PISA dan TIMSS. Yogyakarta: PPPPTK Matematika. 